\title{
Efek Ekstrak Kulit Manggis (Garcinia mangostana) Terhadap Murine Sepsis Score (MSS) Mencit Sepsis yang Diinduksi Shigella dysenteriae
}

\section{Effect of Mangosteen Peel Extract (Garcinia mangostana) on Murine Sepsis Score (MSS) in Sepsis Mice Induced with Shigella dysenteriae}

\author{
Pradipta Reza Syahruna ${ }^{1}$, Arifa Mustika ${ }^{2 *}$, Muhammad Faizi ${ }^{3}$ \\ ${ }^{1}$ Program Studi Kedokteran, ${ }^{2}$ Departemen Farmakologi dan Terapi, ${ }^{3}$ Departemen Ilmu Kesehatan Anak, \\ Fakultas Kedokteran, Universitas Airlangga \\ *Corresponding author: arifa-m@ fk.unair.ac.id
}

\begin{abstract}
Abstrak
Penelitian ini untuk mengetahui efek terapi ekstrak kulit manggis (Garcinia mangostana) terhadap sepsis yang diinduksi Shigella dysenteriae. Penelitian ini merupakan penelitian eksperimental, menggunakan 30 mencit dibagi menjadi 5 kelompok. Masing-masing mencit diinjeksi $S$. dysenteriae secara intraperitoneal. Perlakuan hari pertama post injeksi kontrol positif diberi Azithromycin $246 \mathrm{mg} / \mathrm{kgBB}$, kontrol negatif diberi akuades, kelompok perlakuan diberi ekstra kulit manggis dengan dosis sebagai berikut: $\mathrm{K} 1=100 \mathrm{mg} / \mathrm{kgBB}, \mathrm{K} 2=$ $200 \mathrm{mg} / \mathrm{kgBB}$, dan $\mathrm{K} 3=400 \mathrm{mg} / \mathrm{kgBB}$. Perlakuan hari kedua post injeksi sesuai masa inkubasi bakteri skor MSS tiap mencit dihitung. Terdapat korelasi antara pemberian ekstrak kulit manggis dengan skor MSS mencit $(\mathrm{p}<0.05)$, tidak terdapat perbedaan signifikan antara pemberian ekstrak $200 \mathrm{mg} / \mathrm{KgBB}$ dan $400 \mathrm{mg} / \mathrm{kgBB}$ dengan Azithromycin.
\end{abstract}

Kata kunci: kulit manggis, Garcinia mangostana, Shigella dysenteriae, Murine Sepsis Score

\begin{abstract}
This study aimed to determine the effect of mangosteen peel extract (Garcinia mangostana) on Murine Sepsis Score (MSS) in sepsis mice induced by Shigella dysenteriae infection. This study was an experimental study, 30 mice were divided into 5 groups. Each mouse was injected by S. dysenteriae intraperitoneally. On the first day post injection positive control was given Azithromycin $246 \mathrm{mg} / \mathrm{kgBW}$, negative control was given distilled water, the treatment group was given extra mangosteen peels with the following doses: K1= $100 \mathrm{mg} / \mathrm{kg}$ body weight, $K 2=200 \mathrm{mg} / \mathrm{kg}$ body weight, and $\mathrm{K} 3=400 \mathrm{mg} / \mathrm{kg}$ body weight. On the second day post injection according to the bacterial incubation period MSS score for each mouse was calculated. There was a corelation between the administration of mangosteen peel extract with MSS score of mice $(p<0.05)$. There was no significant difference between administration of extracts of $200 \mathrm{mg} / \mathrm{kg}$ and $400 \mathrm{mg} / \mathrm{kg}$ with Azithromycin.
\end{abstract}

Key words: mangosteen peel, Garcinia mangostana, Shigella dysenteriae, Murine Sepsis Score

Received: 24 November 2019

Revised: 1 Desember 2019

Accepted: 27 Desember 2019

\section{PENDAHULUAN}

Sepsis adalah disfungsi organ yang mengancam jiwa disebabkan oleh respons imun yang tidak teregulasi terhadap suatu infeksi (Singer dkk., 2016). Sepsis terjadi ketika mediator kimia yang dilepaskan ke dalam aliran darah untuk melawan infeksi memicu perubahan cascade dapat merusak beberapa sistem organ (Mayo Clinic, 2018). Sebagian besar bakteri yang dapat menyebabkan sepsis adalah bakteri gram negatif (Dewi, 2011). Bakteri gram negatif yang dapat mengakibatkan sepsis adalah Shigella dysenteriae. S. dysenteriae memiliki lapisan Lipopolisakarida (LPS) pada dinding sel. LPS bertindak sebagai endotoksin yang memicu sekresi sitokin pro-inflamasi yang dapat mengakibatkan sepsis (Kumar dkk., 2007).

Tanaman manggis (Garcinia mangostana) diyakini secara turun-temurun memiliki efek 
antimikroba dan antiinflamasi. Berdasarkan penelitian Widowati dkk (2016) ekstrak kulit manggis memiliki aktivitas menghambat produksi molekul-molekul yang terlibat dalam reaksi inflamasi, diantaranya COX-2, IL-6, IL$1 \beta$, dan NO, selain itu, penelitian dari Lee dkk., (2013) mengungkapkan bahwa kulit manggis dan senyawanya dapat menghambat produksi TNF- $\alpha$ dan IL- 6 pada tikus yang dirangsang oleh LPS. Penelitian yang dilakukan Anindya (2012) juga telah membuktikan bahwa ekstrak kulit manggis (Garcinia mangostana) memiliki efek hambatan terhadap pertumbuhan bakteri $S$. dysenteriae pada uji in vitro.

Metode untuk menilai derajat keparahan (severity) sepsis pada model hewan coba adalah dengan Murine Sepsis Score (MSS). Skor MSS dikembangkan oleh Shrum dkk., 2014. Skor ini mengevaluasi gejala klinis yang dialami hewan coba, seperti : derajat ereksi rambut, tingkat kesadaran, aktivitas spontan, respons terhadap rangsangan, kondisi mata, frekuensi napas, dan kualitas napas. Skor $=3$, telah dinyatakan sebagai cut-off point untuk mencit yang mengidap severe sepsis.

Penelitian ini bertujuan untuk mengetahui efek ekstrak kulit manggis terhadap MSS pada model mencit sepsis studi in vivo dan perbedaannya terhadap Azithomycin.

\section{METODE PENELITIAN}

\section{Etik Hewan Coba}

Penelitian dilaksanakan di Laboratorium Farmakologi Fakultas Kedokteran Universitas Airlangga dengan metode eksperimen. Penelitian dilaksanakan dengan dasar sertifikat etik (ethical clearance) Komite Etik Penelitian Kesehatan Fakultas Kedokteran Universitas Airlangga Surabaya dengan nomor seritifikat 159/EC/KEPK/FKUA/2019.

\section{Persiapan Ekstrak Kulit Manggis}

Kulit manggis yang telah didapat dilakukan identifikasi terlebih dahulu. Kulit manggis dikeringkan lalu dihaluskan, selanjutnya dilakukan ekstraksi dengan metode maserasi menggunakan pelarut etanol $96 \%$ selama $3 \times 24$ jam yang kemudian dipekatkan dengan rotary evaporator, dan dibuat suspensinya dengan (Carboxyl Methyl Celullose) CMC Na 1\% sebagai suspensator.

\section{Pembuatan Model Hewan Coba}

Hewan coba berupa mencit (Mus muculus) berusia \pm 8 -12 minggu yang ekuivalen dengan manusia usia 30-40 tahun (Flurkey dkk., 2007) dengan berat \pm 25 gram, diinfeksikan dengan suspensi bakteri lewat jalur transmisi intraperitoneal sesuai untuk infeksi $S$. dysenteriae pada mencit (Sharma dkk., 2017).

\section{Perlakuan}

Sebanyak 30 mencit dibagi menjadi 5 kelompok. Masing-masing mencit diinjeksi $S$. dysenteriae secara intraperitoneal. Perlakuan hari pertama post injeksi kontrol positif diberi Azithromycin $246 \mathrm{mg} / \mathrm{kgBB}$, kontrol negatif diberi akuades, kelompok perlakuan diberi ekstra kulit manggis dengan dosis sebagai berikut : $\mathrm{k} 1$ $=100 \mathrm{mg} / \mathrm{kgBB}, \mathrm{k} 2=200 \mathrm{mg} / \mathrm{kgBB}$, dan $\mathrm{k} 3=$ $400 \mathrm{mg} / \mathrm{kgBB}$. Perlakuan hari kedua post injeksi sesuai masa inkubasi bakteri skor MSS tiap mencit dihitung dengan menjumlah semua skor dalam 7 variabel (Tabel 1).

\section{Analisis Data}

Data dianalisis menggunakan SPSS versi 16 meliputi uji Kruskal-Wallis untuk menilai adanya pengaruh variabel bebas dan terikat secara umum. Kemudian data diuji lanjut dengan Mann-Whitney untuk membandingkan hasil antar kelompok $(\mathrm{p}<0.05)$.

\section{HASIL DAN PEMBAHASAN}

Hasil rata-rata skor MSS pada kelompok kontrol positif, kelompok perlakuan 2 dan kelompok perlakuan 3 adalah 0,6667 , tetapi terdapat beberapa perbedaan pada variabel penyusun skor MSS dari ketiga kelompok perlakuan tersebut. Kelompok kontrol positif, skor 1 tidak didapatkan pada variabel respons terhadap rangsang, kondisi mata, frekuensi napas, dan kualitas napas (Gambar 1), hal ini diduga karena terdapat perbedaan mekanisme 
Tabel 1. Skor Murine Sepsis Score (MSS)

\begin{tabular}{|c|c|}
\hline Variabel & Skor dan deskripsi \\
\hline Penampilan & $\begin{array}{l}\text { 0: terlihat tenang } \\
\text { 1: sebagian rambut piloereksi } \\
\text { 2: mayoritas rambut punggung piloereksi } \\
\text { 3: piloereksi dapat ada atau tidak, mencit tampak "puffy" } \\
\text { 4: piloereksi dapat ada atau tidak, mencit tampak terlihat kurus kering }\end{array}$ \\
\hline Kesadaran & $\begin{array}{l}\text { 0: aktif } \\
\text { 1: aktif tetapi menghindari berdiri tegak } \\
\text { 2: aktivitas melambat, tetapi masih bergerak } \\
\text { 3: aktivitas terganggu, hanya bergerak bila diprovokasi dan muncul tremor } \\
\text { 4: aktivitas sangat terganggu, tidak merespons rangsang dan kemungkinan tremor }\end{array}$ \\
\hline Aktivitas & $\begin{array}{l}\text { 0: aktivitas makan, minum, memanjat (kandang), berlari, dll normal } \\
\text { 1: aktivitas sedikit berkurang, hanya memutari kandang } \\
\text { 2: aktivitas berkurang, hanya diam dengan sesekali memperhatikan pergerakan } \\
\text { 3: tanpa aktivitas, diam } \\
\text { 4: tanpa aktivitas, terdapat tremor di kaki belakang }\end{array}$ \\
\hline $\begin{array}{l}\text { Respons } \\
\text { terhadap } \\
\text { stimulus }\end{array}$ & $\begin{array}{l}\text { 0: respons segera terhadap rangsang suara atau sentuh } \\
\text { 1: lambat tanpa respons terhadap rangsang suara, respons kuat terhadap sentuhan } \\
\text { 2: tanpa respons terhadap rangsang suara, respons sedang terhadap sentuhan } \\
\text { 3: tanpa respons terhadap rangsang suara, respons lemah terhadap sentuhan } \\
\text { 4: tanpa respons terhadap rangsang suara, sedikit atau tidak merespons terhadap } \\
\text { sentuhan (tidak berpindah), tidak dapat berdiri tegak bila didorong }\end{array}$ \\
\hline Mata & $\begin{array}{l}\text { 0: terbuka } \\
\text { 1: tidak terbuka sempurna, mungkin terdapat kotoran } \\
\text { 2: tertutup separuh, mungkin terdapat kotoran } \\
\text { 3: tertutup lebih dari separuh, mungkin terdapat kotoran } \\
\text { 4: tertutup keseluruhan atau berwarna putih (milky) }\end{array}$ \\
\hline Frekuensi Napas & $\begin{array}{l}\text { 0: normal, pernapasan mencit cepat } \\
\text { 1: sedikit melambat (tidak terhitung dengan melihat) } \\
\text { 2: cukup melambat (kisaran atas dapat terhitung dengan melihat) } \\
\text { 3: sangat lambat (mudah dihitung dengan melihat, jarak antar napas } 0,5 \text { detik) } \\
\text { 4: melambat secara ekstrem ( }>1 \text { detik tiap napas) }\end{array}$ \\
\hline Kualitas Napas & $\begin{array}{l}\text { 0: normal } \\
\text { 1: sedikit bernapas keras/laboured breathing } \\
\text { 2: bernapas keras/laboured breathing, tanpa gasping } \\
\text { 3: bernapas keras/laboured breathing dengan sedikit gasping } \\
\text { 4: gasping }\end{array}$ \\
\hline
\end{tabular}

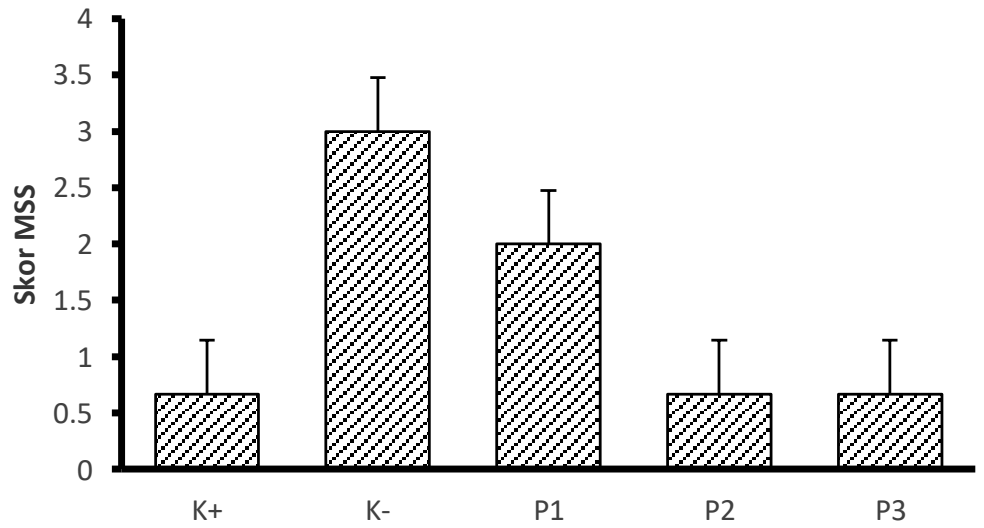

Gambar 1. Rata-rata skor MSS tiap kelompok perlakuan 
kerja antara Azithromycin dan ekstrak kulit manggis (Garcinia mangostana). Individu pada kelompok perlakuan 1 memiliki skor MSS 3, hal ini menunjukkan bahwa individu tersebut mengalami sepsis berat, karena menurut Shrum dkk, (2014) skor 3 digunakan sebagai cut-off untuk mencit yang mengarah pada sepsis berat (severe sepsis), meski demikian rata-rata skor MSS pada kelompok perlakuan 1 masih lebih baik daripada kelompok kontrol negatif aquadest yang memiliki rata-rata skor MSS paling besar, selain itu, pada kelompok perlakuan 1 didapatkan pula beberapa individu yang memiliki skor MSS $<3$ yang berarti individu tersebut tidak mengalami sepsis berat (Gambar 1).

Hasil Skor MSS pada seluruh perlakuan didapatkan bahwa dosis $200 \mathrm{mg} / \mathrm{kgBB}$ dan 400 $\mathrm{mg} / \mathrm{kgBB}$ tidak memiliki beda yang signifikan dengan terapi Azithromycin, tetapi ketiga dosis (100 mg/kgBB, $200 \mathrm{mg} / \mathrm{kgBB}$, dan 400 $\mathrm{mg} / \mathrm{kgBB}$ ) memiliki beda signifikan dengan kelompok kontrol negatif (hanya diberi aquadest). Perbedaan paling signifikan ditemukan pada dosis $200 \mathrm{mg} / \mathrm{kgBB}$ dan $400 \mathrm{mg} / \mathrm{kgBB}$.

Uji Kruskal-Wallis digunakan untuk menilai adanya pengaruh variabel bebas dan terikat secara umum, didapatkan nilai $\mathrm{p}<0.05$ yang berarti ada korelasi secara umum antara ekstrak kulit manggis dan skor MSS.

Uji Mann Whitney memberikan hasil bahwa kontrol positif (Azithromycin $246 \mathrm{mg} / \mathrm{kgBB}$ ) dan kontrol negatif memilki perbedaan signifikan $(\mathrm{p}<0.05)$. Kelompok ekstrak kulit manggis 100 $\mathrm{mg} / \mathrm{kgBB}$ memiliki perbedaan signifikan terhadap kontrol positif $(\mathrm{p}<0.05)$, perbedaan ini bila dihubungkan dengan rata-rata skor MSS menunjukkan bahwa efek terapi dengan dosis $100 \mathrm{mg} / \mathrm{kgBB}$ masih kurang baik dibandingkan dengan Azithromycin, namun, kelompok perlakuan 1 memiliki perbedaan signifikan dengan kontrol negatif $(\mathrm{p}<0.05)$.

Kelompok ekstrak kulit manggis 200 $\mathrm{mg} / \mathrm{kgBB}$ dan $400 \mathrm{mg} / \mathrm{kgBB}$ masing-masing tidak memiliki perbedaan pengaruh dengan kontrol positif dengan ( $>00.05)$, hal ini menunjukkan bahwa terapi dengan ekstrak kulit manggis $200 \mathrm{mg} / \mathrm{kgBB}$ memiliki efek yang sama dengan Azithromycin. Kelompok perlakuan 2 dan 3 masing-masing memiliki perbedaan signifikan dengan kontrol negatif (aquadest) $(\mathrm{p}<0.05)$.

Beberapa hasil di atas menunjukkan bahwa pada dosis $100 \mathrm{mg} / \mathrm{kgBB}$, ekstrak kulit manggis telah memiliki efek terapi tetapi masih belum optimal, selain itu, hasil Skor MSS pada seluruh perlakuan didapatkan bahwa dosis $200 \mathrm{mg} / \mathrm{kgBB}$ dan $400 \mathrm{mg} / \mathrm{kgBB}$ tidak memiliki beda yang signifikan dengan terapi Azithromycin, sehingga efektivitas paling baik terdapat pada rentang kedua dosis tersebut.

Rata-rata skor MSS pada kelompok Azithromycin memiliki nilai yang sama dengan kelompok ekstrak kulit manggis $200 \mathrm{mg} / \mathrm{kgBB}$ dan $400 \mathrm{mg} / \mathrm{kgBB}$. Pada ketiga kelompok perlakuan ini, mayoritas mencit memiliki skor MSS 0 yang berarti tidak terdapat tanda dan gejala sepsis, hal ini sesuai dengan penelitian Sitti dkk., (2018); Hidayahti dan Wardani, (2016); dan Anindya (2012) bahwa ekstrak kulit manggis mampu menghambat pertumbuhan $S$. dysenteriae secara in vitro. Penelitian lain oleh Jacob dkk., (2019) dan Asifa (2014), diketahui bahwa ekstrak kulit manggis juga mampu menghambat pertumbuhan bakteri gram negatif lain yaitu E. coli dan S. flexneri.

Perbedaan yang paling mencolok antara Azithromycin dan ekstrak kulit manggis adalah adanya efek antiinflamasi pada ekstrak kulit manggis, sedangkan Azithromycin hanya memiliki sifat antibakteri (Rothermel, 2003). Azithromycin merupakan antibiotik golongan macrolide yang memiliki sifat bakteriostatik dengan menghambat sintesis protein dan translasi pada bakteri, selain itu, Azithromycin dapat berakumulasi di berbagai jenis sel dan jaringan. Kemampuan Azithromycin untuk penetrasi dan terkonsentrasi di sel berperan dalam farmakokinetik zat ini yaitu memiliki waktu paruh yang lama dan terkonsentrasi dalam jumlah besar di jaringan (Rothermel, 2003).

Efek terapi ekstrak kulit manggis (Garcinia mangostana) terdiri dari efek antibakteri dan efek antiinflamasi dari senyawa xanthone. Senyawa xanthone yang terdapat dalam ekstrak 
kulit manggis mampu menghambat produksi molekul-molekul yang terlibat dalam reaksi inflamasi, diantaranya COX-2, IL-6, IL-1 $\beta$, dan NO. Penelitian oleh Bumrungpert dkk., (2010) menunjukkan bahwa senyawa xanthone mampu menghambat ekspresi gen inflamasi yang diinduksi Lipopolisakarida (LPS), penelitian Kumar dan Chowdury, (2015) juga mengemukakan bahwa adanya efek ekstrak kulit manggis dalam mengurangi produksi NO pada inflamasi yang diinduksi LPS. Senyawa xanthone yang terdapat di ekstrak kulit manggis (Garcinia mangostana) juga berperan menghambat produksi Reactive Oxygen Species (ROS) intrasel dan juga memiliki sifat antioksidan berupa kemampuan memberi atom hidrogen dengan cara memutus rantai radikal bebas.

\section{KESIMPULAN}

Ekstrak kulit manggis dosis $200 \mathrm{mg} / \mathrm{kgBB}$ signifikan memberikan efek terapi pada mencit sepsis yang diinduksi infeksi $S$. dysenteriae yang diukur dari MSS. Rata-rata MSS pada dosis 200 $\mathrm{mg} / \mathrm{kgBB}$ juga tidak menunjukkan perbedaan signifikan dibandingkan Azithromycin 246 $\mathrm{mg} / \mathrm{kgBB}$.

\section{UCAPAN TERIMA KASIH}

Terima kasih kepada Laboratorium Farmakologi Fakultas Kedokteran Universitas Airlangga di Surabaya yang telah memfasilitasi pelaksanaan penelitian ini.

\section{DAFTAR PUSTAKA}

Anindya, D. 2012. Efek Ekstrak Kulit Buah Manggis (Garcinia Mangostana L.) Terhadap Pertumbuhan Bakteri Shigella dysentriae dan Escherichia coli. [Skripsi]. Fakultas Kedokteran dan Ilmu Kesehatan. UIN Syarif Hidayatullah Jakarta.

Asifa, U.S. 2014. Uji Aktivitas Antibakteri Frakti n-Heksana Kulit Buah Manggis (Garcinia mangostana L.) Terhadap
Pertumbuhan Shigella flexneri Secara In Vitro. Jurnal Mahasiswa Fakultas Kedokteran Untan, 1(1), 1-17.

Bumrungpert, A., Kalpravidh, R.W., Chuang, C., Overman, A., Martinez, K., Kennedy, A., Mcintosh, M. 2018. Xanthones from Mangosteen Inhibit Inflammation in Human Macrophages and in Human Adipocytes Exposed to Macrophage-Conditioned Media. J. Nutr., 140(6), 4-9.

Dewi, R. 2011. Sepsis pada Anak: Pola Kuman dan Uji Kepekaan. Maj. Ked. Indones., 61(3), 104.

Flurkey, K., Currer, J.M., Harrison, D.E. 2007. The Mouse in Aging Research. In Fox, J.G., Barthold, S.W., Davisson, M.T., Newcomer, C.E., Quimby, F.W., Smith, A.L. The Mouse in Biomedical Research (2). Massachusetts: Elsevier, p637-672.

Hidayahti, N., Wardani, D.E. 2015. Daya Hambat Rebusan Kulit Buah Manggis (Garcinia mangostana Linn) Terhadap Pertumbuhan Bakteri Salmonella typhi dan Shigella dysentriae. J. Sains, 5(10).

Jacob, D., Vigasini, N., Iyer, P. R. 2016. Antibacterial Activity Of Mangosteen (Garcinia Mangostana) Pericarp. World J. Pharm. Res., 5(9), 1797-1802.

Kumar, V., Abbas, A.K., Fausto, N. 2007. Robbins Basic Pathology. 8th edition. Saunders, Elsevier.

Kumar, S., Chowdhury, S. 2015. AntiInflammatory Effect Of An Ethyl Acetate Extract Of Garcinia mangostana L. By Downregulation Of Nitric Oxide Production In RAW 264.7 Cell Line. Int. J. Pharm. Biol. Sci., 5(2), 229-233.

Kusuma, S.A.F., Wardhani, P., Febrina, E. 2017. Stool Form Scale As An Indicator Of Klutuk Banana (Musa Balbisiana Colla) Fruit 
Extracts Inhibition Effect Against Shigella Dysenteriae ATCC 13313. As. J. Pharm. Clin. Res., 10(12), 18-20.

Lee, L.T., Tsai, Y.F., Hu, N.Y., Wang, C.W., Huang, K.K., Hsiao, J.K., Shih, Y.C., Munekazu, I. 2013. Anti-arthritis effect of mangostins from G. Mangostana. Biomed. Prev. Nutr., 3(3), 227-232.

Mayo Clinic. 2018. Sepsis - Symptoms and causes. [online] Available at: https://www.mayoclinic.org/diseasesconditions/sepsis/symptoms-causes/syc20351214 [Accessed 28 Apr. 2018].

Rothermel, C.D. 2003. Single Dose Azithromycin for Acute Otitis Media: A Pharmacokinetic/Pharmacodynamic

Rationale. Curr. Ther. Res. Clin. Exp., 64(1), 4-15.

Sharma, D., Yagnik, B., Baksi, R., Desai, N., Padh, H., Desai, P. 2017. Shigellosis murine model established by intraperitoneal and intranasal route of administration: A comparative comprehension overview. Microb. Infection, 19(1), 47-54.
Shrum, B., Anantha, R.V., Xu, S.X., Donnelly, M., Haeryfar, S.M.M., McCormick, J.K., Mele, T. 2014. A robust scoring system to evaluate sepsis severity in an animal model. BMC Research Notes, 7(1), 1-11.

Sitti, R., Sugita, P., Ambarsari, L., Rahayu, D. 2018. Antibacterial Mangosteen (Garcinia mangostana Linn.) peel extract encapsulated in Chitosan. J. Physics: Conf. Series, 1116(4), 042037.

Singer, M., Deutschman, C.S., Seymour, C.W. 2016. The third international consensus definitions for sepsis and septic shock (Sepsis-3). JAMA, 315(8), 801-810.

Widowati, W., Darsono, L., Suherman, J., Fauziah, N. 2016. Anti-inflammatory Effect of Mangosteen (Garcinia mangostana L.) Peel Extract and its Compounds in LPSinduced RAW264.7 Cells. Nat. Prod. Sci., 22(3), 147-153. 